\title{
Diagnosis and Treatment of Acute Tubular Necrosis
}

Matthew L. Esson, MD, and Robert W. Schrier, MD

Background: Acute tubular necrosis (ATN) is common in hospitalized patients, particularly in the intensive care unit. Over the past four decades, the mortality rate from ATN has remained at $50 \%$ to $80 \%$.

Purpose: To review recent studies of diagnosis and treatment strategies for ATN.

Data Sources: MEDLINE search for all clinical studies of therapies for ATN, supplemented by a review of the references of the identified articles.

Study Selection: Prospective studies and major retrospective studies evaluating therapies for ATN.

Data Extraction: Data on the study sample, interventions performed, results, side effects, and duration of follow-up.

Data Synthesis: Early diagnosis of ATN by exclusion of prerenal and postrenal causes of acute renal failure, examination of urinary sediment, and analysis of urine measures (for example, fractional excretion of sodium in the absence of diuretics) can allow the early involvement of nephrologists and improve survival. Enteral rather than parenteral hyperalimentation in severely malnourished patients may improve survival. Sepsis causes $30 \%$ to $70 \%$ of deaths in patients with ATN; therefore, avoidance of intravenous lines, bladder catheters, and respirators is recommended. Because septic patients are vasodilated, large volumes of administered fluid accumulate in the lung interstitium of these patients. This condition necessitates ventilatory support, which when prolonged leads to acute respiratory distress syndrome, multiorgan failure, and increased mortality. More aggressive dialysis (for example, given daily) with biocompatible membranes may improve survival in some patients with acute renal failure.

Conclusions: New information about the importance of early diagnosis and supportive care for patients with ATN has emerged. However, randomized trials of these interventions are needed to test their effect on the morbidity and mortality of ATN.

Ann Intern Med. 2002;137:744-752.

www.annals.org

For author affiliations, see end of text.
A cute tubular necrosis (ATN) is a common condition among hospitalized patients and patients in intensive care units (ICUs). Arising as a consequence of septic, toxic, or ischemic insult, ATN is a potentially reversible process, but patients frequently die before renal recovery as a result of comorbid illness and ATN itself. Pharmacologic therapies to prevent or alter the course of ATN, while promising, have in general been unsuccessful. Despite technological advances in dialysis, the mortality rate in patients with ATN who require dialysis remains between $50 \%$ and $80 \%$.

\section{Methods}

We performed a comprehensive MEDLINE search of all clinical studies of therapies for acute renal failure published from 1966 to the present. When possible, we included randomized, controlled trials in addition to major retrospective studies and prospective observational studies. Data on the study sample, interventions performed, results, side effects, and duration of follow-up were extracted. We also searched MEDLINE for major review articles and laboratory investigations on acute renal failure and reviewed the references of the selected articles. We summarize the design and results of the studies included in our review, but we did not do a formal meta-analysis because of the broad range of treatment strategies examined, the heterogeneity of study designs, and the small number of patients involved in these studies.

\section{ATN DEFINED \\ Definition}

Acute tubular necrosis is characterized by a sudden decline in glomerular filtration rate (GFR); accumulation of nitrogenous wastes; and an inability of the kidney to regulate the balance of sodium, electrolytes, acid, and water. However, no uniform diagnostic criteria for ATN exist (1). Commonly used criteria include a 50\% decline in calculated GFR or a $0.5-\mathrm{mg} / \mathrm{dL}(40-\mu \mathrm{mol} / \mathrm{L})$ increase in serum creatinine level. "Acute renal failure" and "acute tubular necrosis" are often used interchangeably. However, a variety of other conditions, including prerenal azotemia, urinary tract obstruction, vasculitis, glomerulonephritis, and acute interstitial nephritis, can also cause acute renal failure. Nevertheless, ischemic or toxic ATN is the predominant cause of acute renal failure among hospitalized patients (2).

\section{Caveats about Interpreting Blood Urea Nitrogen and Serum Creatinine Levels}

The physician must carefully interpret clinical markers of impaired GFR, including an increase in blood urea nitrogen (BUN) and serum creatinine levels. Levels of BUN depend on the exogenous urea load (intake), endogenous urea production (catabolic rate), and tubular reabsorption. In prerenal azotemic states (for example, volume depletion), enhanced reabsorption of urea from the medullary collecting duct may lead to an elevation of BUN level that is disproportionate to the increase in serum creatinine level (ratio $>10$ to $15: 1$ ). While creatinine in muscle is produced at a constant rate, the creatinine level in the blood can be elevated during catabolic states such as rhabdomyolysis. Aggressive fluid administration may dilute the serum creatinine level. Furthermore, increased tubular secretion of creatinine occurs at low GFRs, and thus creatinine clearance substantially overestimates GFR. Moreover, 
Table 1. Urine Laboratory and Microscopic Findings in Prerenal Azotemia and Acute Tubular Necrosis

\begin{tabular}{|c|c|c|}
\hline Laboratory Test & Prerenal Azotemia & Acute Tubular Necrosis \\
\hline $\begin{array}{l}\text { Urine osmolality, } \\
\text { mOsm/kg }\end{array}$ & $>500$ & $<400$ \\
\hline $\begin{array}{l}\text { Urine sodium level, } \\
\qquad \mathrm{mEq} / \mathrm{L}\end{array}$ & $<20$ & $>40$ \\
\hline $\begin{array}{l}\text { Urine-plasma } \\
\text { creatinine ratio }\end{array}$ & $>40$ & $<20$ \\
\hline $\begin{array}{c}\text { Fractional secretion } \\
\text { of sodium, \% }\end{array}$ & $<1$ & $>2$ \\
\hline Urinary sediment & $\begin{array}{l}\text { Normal, occasional } \\
\text { hyaline or finely } \\
\text { granular cast }\end{array}$ & $\begin{array}{l}\text { Renal tubular epithelial } \\
\text { cells, granulars and } \\
\text { muddy brown } \\
\text { granular casts }\end{array}$ \\
\hline
\end{tabular}

drugs such as cimetidine and trimethoprim, which inhibit tubular secretion of creatinine, cause an increase in serum creatinine level in the absence of changes in GFR (3). Moran and Myers (4) have characterized various patterns of hemodynamically mediated ATN and the delayed increase and decrease of serum creatinine level in response to underlying changes in GFR.

\section{Delayed Recognition of ATN}

Recognition of ATN and evaluation of its severity may be delayed by overreliance on surrogate markers of GFR and underappreciation of their shortcomings. The absence of oliguria may also delay recognition of the severity of ATN. Nonoliguric ATN often, but not always, carries an improved prognosis compared with oliguric ATN (5). Delayed nephrologic consultation may contribute to adverse outcomes in patients with ATN $(6,7)$. The reason for these observations is unclear, particularly in view of the absence of proven therapies for ATN. Nonetheless, early recognition of ATN, removal of offending agents, and meticulous attention to supportive care may be beneficial. Furthermore, early recognition of the onset of ATN may spare the patient excessive administration of crystalloid and other fluids that can lead to noncardiac pulmonary edema. We have termed this state "pseudo acute respiratory distress syndrome" (pseudo ARDS) because pulmonary compliance is initially normal (see discussion later in this paper) (8). Excessive fluid administration can produce many adverse physiologic effects that lead to classic ARDS and increased mortality.

\section{AtN: The Major Cause of Acute Renal Failure Diagnosis of ATN}

Early recognition of ATN relies on clinical tools more commonly used by nephrologists than by other medical specialists (Table 1). In the setting of impaired renal perfusion, low urine sodium concentration and fractional excretion of sodium, elevated urine osmolality, and elevated urine-plasma creatinine ratio indicate preserved tubular function and an appropriate renal response to the prerenal azotemic state. With the onset of ATN, tubular dysfunc- tion leads to an increase in urinary sodium concentration and fractional excretion of sodium ([urine sodium/plasma sodium]/[urine creatinine/plasma creatinine] $\times 100$ ), and an impairment in urinary concentrating capacity characterized by a decrease in urine osmolality and urine-plasma creatinine ratio (9). The physician must be aware, however, that advanced chronic renal failure and recent diuretic use may alter the utility of these urinary measures. Furthermore, ATN in the setting of rhabdomyolysis and myoglobinuria, hemolysis, sepsis, cirrhosis, heart failure, and radiocontrast nephropathy may be associated with a low urinary sodium concentration (for example, $<10 \mathrm{mEq} / \mathrm{L}$ ) and fractional excretion of sodium (for example, $<1.0 \%$ ) (10-13). Recognition of the characteristic urinary sediment of ATN, including renal tubular epithelial cells, granular casts, and muddy brown granular casts (Figure), helps make the diagnosis. However, since there is no gold standard, the diagnostic approach must rely on a synthesis of

Figure. Characteristic microscopic findings from the urine sediment of a patient with acute tubular necrosis.

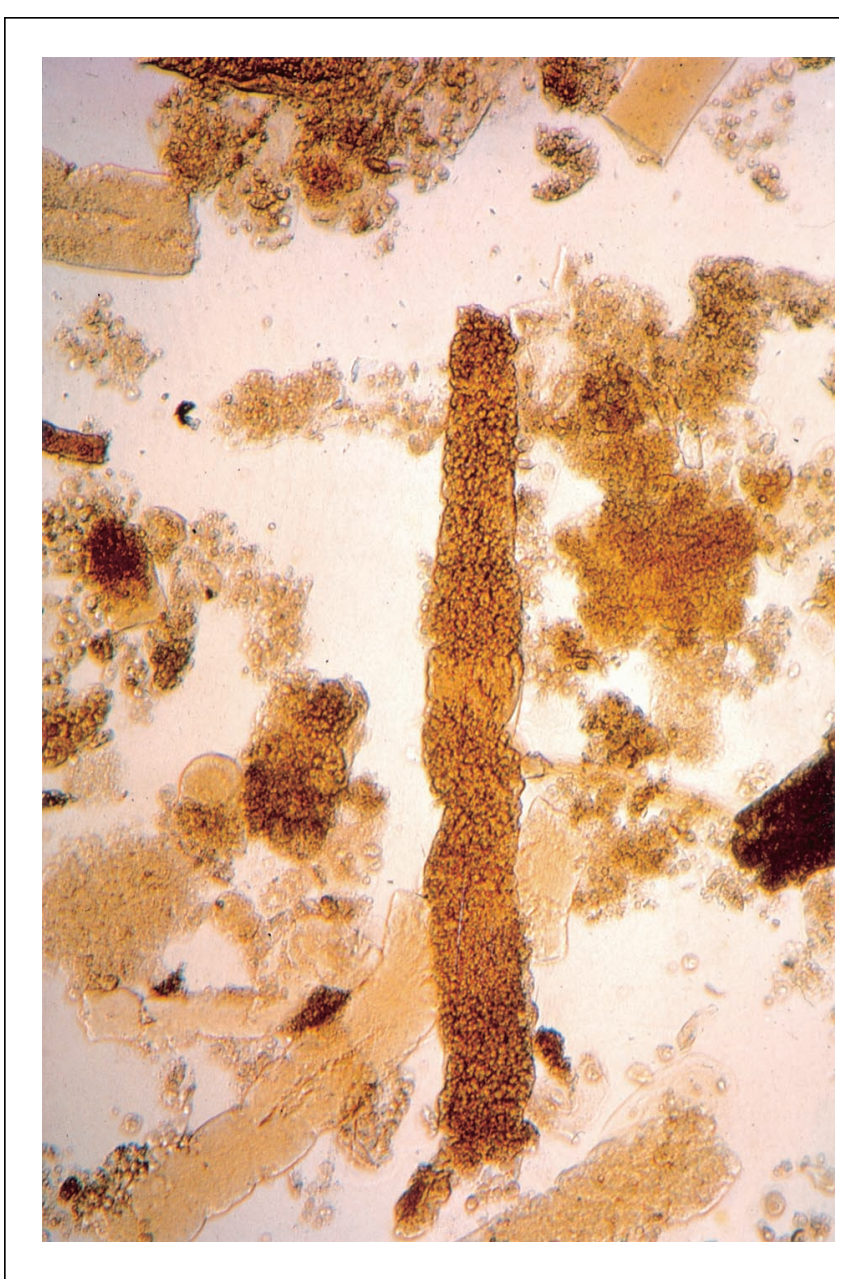

The muddy brown granular casts, amorphous debris, and renal tubular epithelial cells are consistent with tubular injury. (Original magnification, $\times 400$.)

5 November $2002 \mid$ Annals of Internal Medicine $\mid$ Volume $137 \bullet$ Number $9 \mid 745$ 
data from the patient's history, physical examination, and laboratory studies.

\section{Epidemiology and Outcomes of ATN}

Acute tubular necrosis has been reported as the leading cause of acute renal failure among hospitalized patients and patients in ICUs, accounting for $38 \%$ and $76 \%$ of cases of acute renal failure, respectively (1). Mortality from ATN in hospitalized and ICU patients was $37.1 \%$ and $78.6 \%$, respectively (14). Survivors of ATN generally have a good prognosis for renal recovery. Full renal recovery has been reported as $56 \%$ to $60 \%$, but between $5 \%$ and $11 \%$ of these patients ultimately need long-term dialysis (15-17). Among surviving ICU patients with ATN who require dialysis, however, up to $33 \%$ may need long-term dialysis, and $28 \%$ may require institutional care (18).

Sepsis was the leading cause of ATN in a prospective French study of acute renal failure in the ICU (19). Various risk factors for increased mortality in ATN have been identified, including male sex, advanced age, comorbid illness, malignancy, oliguria, sepsis, mechanical ventilation, multiorgan failure, and severity-of-illness score $(18,20)$. Traditional models of predicting death in critically ill patients, such as the Acute Physiology and Chronic Health Evaluation II (APACHE II) system, underestimate the risk for death in patients with ATN. These models underestimate the interaction between ATN and the effects of other comorbid events that occur in multiorgan failure. For this reason, severity-of-illness scores designed specifically for ATN have been developed $(21,22)$. Models designed by Liaño and colleagues (21) and by the Cleveland Clinic have been prospectively validated (23-25).

It is now established that ATN independently and significantly affects patient survival. In a controlled study of ATN following radiocontrast procedures, Levy and colleagues (26) found that ATN increased the odds ratio for death by 5.5. Patients with ATN in this study were more likely than other inpatients to have hospital courses complicated by sepsis, respiratory failure, delirium, and bleeding. Renal replacement therapy does not eliminate the risk for death in patients with ATN.

\section{THERAPY FOR ATN}

\section{Prevention and Reversal of ATN}

Because of the frequency and high mortality of ATN, particularly in ICUs, randomized interventional trials are needed to evaluate methods for decreasing the occurrence, duration, and severity of ATN $(6,27-31)$. As in experimental ATN, it is clear that implementing an intervention before the toxic or ischemic insult affords the best opportunity for preventing or attenuating the course of ATN. For example, ATN has been prevented or attenuated in high-risk patients with chronic renal failure with or without diabetes by using nonionic rather than ionic radiocontrast media (32). More recently, acetylcysteine $(600 \mathrm{mg}$ twice daily) has been shown to decrease the risk for renal insufficiency secondary to radiocontrast media (increase in serum creatinine level $>0.5 \mathrm{mg} / \mathrm{dL}[40 \mu \mathrm{mol} / \mathrm{L}])$ from $21 \%$ to $2 \%(P<0.001)$ (33). In patients who have received cadaveric kidney transplants, mannitol and calciumchannel blockers may maintain GFR and decrease the need for dialysis $(34-43)$.

The story is quite different when intervention begins after ATN occurs. Some maneuvers, such as the administration of dopamine or high-dose loop diuretics, convert oliguric to nonoliguric ATN in humans, but they have no effect on the duration of ATN, need for dialysis, or survival (44-53). Studies in animal models have shown beneficial effects when an intervention has been administered after ATN develops (for example, $\alpha$-melanocyte-stimulating hormone and atrial natriuretic peptide) (54-57).

These single-insult animal models, however, do not mimic the many insults that frequently occur in ATN in humans. In a study of 53 patients with established ATN randomly assigned to atrial natriuretic peptide or placebo, intrarenal and intravenous atrial natriuretic peptide improved creatinine clearance and decreased the need for dialysis (58). Subsequent larger randomized trials, however, failed to confirm this benefit $(59,60)$. The decrease in blood pressure during intravenous atrial natriuretic peptide therapy may have obscured any beneficial renal effects. The beneficial role of growth factors in enhancing the rate of recovery from ATN in animal models was not reproducible in humans $(61,62)$. Taken together, these studies have not shown that medical therapy alters the course of established ATN.

\section{Hemodynamic Support}

In the absence of therapies with proven beneficial effect in ATN, appropriate supportive care is mandated. Aside from avoidance of further nephrotoxic insults, such as nonsteroidal anti-inflammatory drugs, nephrotoxic antibiotics, and radiocontrast media, ensuring adequate hemodynamics and thus renal perfusion pressure is the cornerstone of care. In a series of renal biopsy samples from 57 patients with protracted ATN, Solez and colleagues (63) demonstrated fresh necrotic tubular cells consistent with recurrent ischemic damage. Animal models have advanced the understanding of this predisposition of the ATN kidney for recurrent injury. After renal artery clamp-induced ischemia, dogs and rats have impaired autoregulation of GFR and renal blood flow throughout all ranges of mean arterial pressure. In these experimental ATN models, renal perfusion is linearly dependent on mean arterial pressure even in the normal range of blood pressure. Furthermore, paradoxical renal vasoconstriction occurs at low mean arterial pressure $(64,65)$. In addition, animal models have demonstrated increased intrinsic renal vascular tone and increased sensitivity to vasoconstrictive stimuli that contribute to impaired GFR $(66,67)$. Thus, either mild or severe decreases in blood pressure due to volume depletion, dialysis, sepsis, cardiac dysfunction, anesthesia, or antihypertensive medications can further decrease renal perfusion 
and lead to recurrent ischemic injury. Such a hemodynamic insult delays recovery from ATN, thereby increasing mortality.

Ensuring adequate volume status must underlie any treatment strategy. The clinical assessment of volume status in a critically ill patient, however, is often difficult. Overzealous fluid administration (for example, 10 to $15 \mathrm{~L}$ ) in an attempt to improve hemodynamics in a septic patient with leaky pulmonary vasculature can precipitate noncardiogenic pulmonary edema (pseudo ARDS) (8). Because of pseudo ARDS, patients are placed on ventilators, with the attendant potential infections, barotrauma, and oxygen toxicity, and are classified as having multiorgan failure. In this setting, physicians frequently use invasive measures of volume status, including those obtained from central venous and pulmonary artery catheters. This practice has recently been questioned $(68-70)$ because evidence indicates an association between right-heart catheterization and increased mortality, length of hospital stay, and cost of care (71). A randomized, controlled study is necessary to further examine this issue (72). Moreover, recent studies suggest that increasing cardiac output and oxygen delivery with the administration of large volumes of fluids and inotropic agents and aggressive red blood cell transfusion may actually increase mortality (73-76). For patients in a vasodilated, septic state, carefully measured daily body weight and fluid balance may be better indices of fluid volume than are measurements obtained through pulmonary artery catheters-fluid leakage into the pulmonary interstitium may necessitate oxygen therapy and ventilator support even when the pulmonary capillary wedge pressure is normal.

The literature provides little guidance on the choice of vasoactive agents to maintain an adequate mean arterial pressure without further constricting kidney vessels (77). Clearly, $\alpha$-adrenergic agents cause renal vasoconstriction and therefore can prevent recovery from ATN. In septic patients with vasodilation, vasopressin may increase systemic vascular resistance without substantially constricting the kidney. Selective use of "renal-dose" dopamine has not been shown to be of value $(78-81)$. Bellomo and colleagues (82) recently reported on 328 critically ill patients with acute renal failure who were randomly assigned to continuous infusions of placebo or low-dose dopamine (2 $\mu \mathrm{g} / \mathrm{kg}$ of body weight per minute). Peak serum creatinine concentration, requirement for dialysis, length of hospital stay, and mortality did not differ between groups.

\section{Nutritional Support}

Critical illness and ATN are states of metabolic stress $(83,84)$. Catabolism of protein stores to support gluconeogenesis can result in marked muscle and visceral protein wasting and is associated with excess morbidity and mortality. Enteral and parenteral nutritional supplementation are frequently used to combat malnutrition.

Moore and colleagues (85) randomly assigned $75 \mathrm{pa}-$ tients with abdominal trauma undergoing laparotomy to enteral or parenteral nutrition after surgery. Enteral nutrition was associated with improved nutritional markers and decreased infectious complications and sepsis compared with parenteral nutrition (85). While enteral feeding is the preferred means of nutritional support, it is not possible in all patients.

In randomized trials to date, total parenteral nutrition in surgical patients has not improved patient survival (86, 87). Among severely malnourished patients, however, parenteral nutrition was associated with a decrease in noninfectious complications (87). A recent meta-analysis by Heyland and coworkers reviewed 26 randomized trials comparing total parenteral nutrition with standard care in a total of 2211 surgical and critically ill patients (88). The authors found no survival benefit of total parenteral nutrition and noted possible harm among patients in a medical ICU treated with total parenteral nutrition. In addition, mounting evidence suggests that administration of lipids may be harmful (89).

Parental nutrition also has not been proven to be of benefit for ATN. With multiorgan dysfunction, uremia is known to accelerate catabolism because of a variety of factors, including acidosis, altered counter-regulatory hormonal status, increase in plasma protease activity, and insulin resistance (90). Abel and colleagues' 1973 randomized study (91) of adult patients with ATN showed that essential amino acid supplementation compared with dextrose alone accelerated recovery of renal function and improved survival for patients undergoing dialysis. Subsequent studies, however, have not confirmed these findings. Feinstein and colleagues (92) could not show a difference in a double-blind study that randomly assigned 30 patients with ATN to one of three isocaloric regimens: glucose alone, glucose plus essential amino acids, or glucose plus essential and nonessential amino acids. Because of the catabolic state of ATN and associated comorbid illness, a positive nitrogen balance is difficult to achieve in these patients $(93,94)$. A recent review has recommended providing protein and nonprotein calories to meet calculated energy expenditures at a rate not to exceed $1.5 \mathrm{~g}$ of protein intake per $\mathrm{kg}$ of body weight per day in patients with ATN (95). Another review by Kopple (96) concluded that nutritional therapy during the first 2 weeks of ATN is of unclear benefit; however, among patients who cannot eat for more than 2 to 3 weeks, nutritional therapy is of likely benefit.

\section{Dialysis \\ Importance of the Biomembranes}

Perhaps because of the nature of the dialysis membrane, hemodialysis may prolong the course of ATN (97). Techniques and materials used in hemodialysis have evolved over recent decades as researchers have sought to decrease the inflammatory and hemodynamic effects of this therapy. Specifically, the degree of biocompatibility of dialysis membranes has been altered to attenuate the inflam- 
REVIEW Diagnosis and Treatment of Acute Tubular Necrosis

Table 2. Studies Comparing Dialysis for Acute Renal Failure That Used Biocompatible Dialyzer Membranes with Dialysis That Used Bioincompatible Membranes

\begin{tabular}{|c|c|c|c|c|c|}
\hline Study & Patients, $n$ & Prospective & Randomized & Placebo-Controlled & $\begin{array}{l}\text { Improved Outcome } \\
\text { with Biocompatible } \\
\text { Membrane }\end{array}$ \\
\hline Hakim et al. (100) & 72 & Yes & Yes & Yes & Yes \\
\hline Himmelfarb et al. (101)* & 153 & Yes & Yes & Yes & Yes \\
\hline Kurtal et al. (102) & 57 & Yes & No & Yes & No \\
\hline Jones et al. (103) & 133 & Yes & Yes & Yes & No \\
\hline
\end{tabular}

* Study participants include the 72 patients from Hakim and colleagues' study.

matory interactions between the blood and the artificial hemodialysis circuit (98). This was considered necessary because the polysaccharide character of the standard cellulose membrane activates the alternate complement cascade, with resultant contraction of vascular smooth-muscle cells and activation of monocytes and neutrophils. Initial trials examining the effect of biocompatible membranes in the dialytic therapy of patients with ATN compared with the effect of bioincompatible membranes indicated improved patient survival among patients treated with biocompatible membranes (99-101). However, some recent trials comparing biocompatible versus bioincompatible dialysis membranes have not shown a positive effect on patient mortality or the duration of ATN (Table 2) (102-105).

In addition to the biocompatibility of the dialyzer membrane used, the dialysis procedure also includes noninflammatory, hemodynamic, osmotic, and metabolic effects that involve rapid intercompartmental shifts of fluids, electrolytes, and metabolic wastes. With the application of continuous renal replacement methods, synthetic membranes, bicarbonate dialysis, and volumetric control of fluid removal, dialysis has recently become less physiologically stressful. Evidence suggests that the survival of patients with ATN has improved in recent years, despite increasing patient age and severity-of-illness scores (106). Whether this is due to the improvements in the dialysis procedure or to changes in nonrenal supportive care or both is not clear.

\section{Initiation and Dose}

The effects of timing of dialysis initiation and the determination of dialysis adequacy in ATN are unknown. The definitions of "early" and "intensive" dialysis have evolved through the years. In 1972, Kleinknecht and colleagues (107) reported on the beneficial effects of "prophylactic" dialysis. In a retrospective study, 279 patients who had dialysis before 1966 were compared with a group of 221 patients who had dialysis from 1968 through 1970. Indications for treatment during the earlier period were a BUN level greater than $164 \mathrm{mg} / \mathrm{dL}(58.5 \mathrm{mmol} / \mathrm{L})$ or uremic complications. During the later period, dialysis was performed to keep the BUN level at less than $93 \mathrm{mg} / \mathrm{dL}$
(33.0 mmol/L) (prophylactic dialysis). Prophylactic dialysis was associated with decreased incidence of gastrointestinal bleeding, septicemia, and mortality. In 1975, Conger (108) reported a small prospective study of soldiers who fought in the Vietnam War and developed ATN due to trauma. Patients were assigned to intensive dialysis to keep the serum creatinine level less than $5 \mathrm{mg} / \mathrm{dL}(440 \mu \mathrm{mol} / \mathrm{L})$ and BUN level less than $70 \mathrm{mg} / \mathrm{dL}(25.0 \mathrm{mmol} / \mathrm{L})$ or to conventional dialysis to keep the serum creatinine level less than $10 \mathrm{mg} / \mathrm{dL}(880 \mu \mathrm{mol} / \mathrm{L})$ and BUN level less than 100 $\mathrm{mg} / \mathrm{dL}(35.5 \mathrm{mmol} / \mathrm{L})$. Mortality was lower with intensive therapy: 3 of 8 patients (36\%) versus 8 of 10 patients $(80 \%)$. Although this observation was statistically significant, this finding needed to be validated in a larger study in a civilian population. In 1986, Gillum and colleagues (109) reported on a prospective paired study in 34 civilians with ATN who were assigned to intensive dialysis (predialysis $\mathrm{BUN}<60 \mathrm{mg} / \mathrm{dL}[<21.5 \mathrm{mmol} / \mathrm{L}]$ and serum creatinine level $<5 \mathrm{mg} / \mathrm{dL}[<440 \mu \mathrm{mol} / \mathrm{L}])$ or to conventional dialysis (BUN level $<100 \mathrm{mg} / \mathrm{dL}[<35.5 \mathrm{mmol} / \mathrm{L}]$ and creatinine level $<9 \mathrm{mg} / \mathrm{dL}[<800 \mu \mathrm{mol} / \mathrm{L}])$. Intensive dialysis resulted in a decrease in hemorrhagic events. Mortality and the course of ATN did not significantly differ between the intensive group and the conventional group, and no effect was seen on the course of ATN.

Recent studies using biocompatible membranes have, however, suggested that increased dialysis dose is beneficial (110). Paganini and colleagues (24) retrospectively examined the effect of delivered dose of dialysis on mortality for critically ill patients with ATN. Among the patients with lowest and highest risk for death, the delivered dose of dialysis had no effect on mortality, but in those at intermediate risk for death, higher dose of dialysis $(>58 \%$ urea reduction ratio) was associated with improved survival. Lack of random patient allocation is a caveat to the significance of these findings. However, Ronco and coworkers (111) demonstrated improved survival in patients with ATN who were randomly assigned to different doses of continuous venovenous hemofiltration. A total of 425 patients with ATN were randomly assigned to increasing rates of ultrafiltration: $20 \mathrm{~mL} / \mathrm{h}$ per $\mathrm{kg}$ of body weight (group 1), $35 \mathrm{~mL} / \mathrm{h}$ per $\mathrm{kg}$ (group 2), or $45 \mathrm{~mL} / \mathrm{h}$ per $\mathrm{kg}$ 
Diagnosis and Treatment of Acute Tubular Necrosis

(group 3). Survival in group $1(41 \%)$ was significantly lower than that in group $2(57 \% ; P<0.001)$ or in group $3(58 \% ; P=0.0013)$. Survival did not significantly differ between groups 2 and $3(P>0.2)$. Moreover, Schiffl and colleagues (112) recently reported that among 160 consecutive patients alternately assigned to daily or alternate-day hemodialysis with a biocompatible membrane (high-flux polysulfone or AN 69), mortality was reduced from $46 \%$ to $28 \%$ with daily dialysis $(P=0.01)$. The weekly delivered dose of dialysis was greater for the daily group than for the alternate-day group. As discussed in an accompanying editorial (113), the $46 \%$ mortality rate in the alternate-day dialysis group was lower than that observed in other studies of dialysis-requiring ATN; this finding suggests that this patient sample was less severely ill than those in previous studies. Assignment of patients to either continuous or intermittent dialysis before enrollment and nonrandom assignment to treatment groups also weakened the study results. Nonetheless, studies to date suggest that increased doses of dialysis via biocompatible membranes may improve outcomes in ATN. In particular, the preselection of a less critically ill subgroup of patients with ATN may lead to a population who benefit from an increased dose of dialysis $(24,113)$.

\section{Method}

Physicians caring for patients with ATN must also select a continuous or an intermittent method of dialysis. The potential benefits of continuous therapy (for example, continuous venovenous hemofiltration) include a slow, controlled rate of fluid and solute removal, less hemodynamic effect, suitability for hypotensive patients, increased cytokine removal, and early delivery of total parenteral nutrition. Disadvantages include patient confinement to bed, increased cost, increased anticoagulation requirement, and, in some retrospective studies, increased mortality (114, 115). Several retrospective and prospective studies have attempted to compare outcomes for continuous versus intermittent dialysis. In a retrospective study of 349 patients who underwent dialysis for ATN at the University of Michigan, Ann Arbor, Michigan, the mortality rate was higher for continuous hemodialysis than for intermittent hemodialysis (68\% vs. $41 \%$; $P<0.001)$ (116). However, when the researchers used a Cox multivariate analysis to adjust for reasons for patient assignment to continuous treatment (for example, systolic blood pressure $<90 \mathrm{~mm}$ $\mathrm{Hg}$, total bilirubin level $>257 \mu \mathrm{mol} / \mathrm{L}[>15 \mathrm{mg} / \mathrm{dL}]$ ), continuous treatment was not associated with an increased risk for death. Mehta and colleagues (117) reported on a randomized multicenter trial that assigned patients to continuous (84 patients) or intermittent (82 patients) therapy. Mortality rates in this study were also higher for continuous than for intermittent therapy. The groups, however, were not well matched, and the continuous therapy group had more men, higher APACHE II and III scores, and

\section{Table 3. Recommendations for Acute Renal Failure*}

1. Evaluate patient for acute renal failure when serum creatinine level increases by $>0.5 \mathrm{mg} / \mathrm{dL}(40 \mu \mathrm{mol} / \mathrm{L})$.

2. Exclude prerenal causes (e.g., volume depletion, cirrhosis, cardiac failure, nonsteroidal anti-inflammatory drugs, angiotensin-converting enzyme inhibitors).

3. Exclude postrenal causes (using renal ultrasonography and measurement of postvoid residual).

4. Review urinary sediment (muddy brown casts: ATN; red blood cell casts: glomerulonephritis or vasculitis; pyuria: acute interstitial nephritis; clear sediment: prerenal or postrenal azotemia)

5. Evaluate urine electrolytes in absence of diuretics (urine osmolality; urine sodium concentration; urine-plasma creatinine ratio; and fractional excretion of sodium).

6. After exclusion of prerenal and postrenal azotemia and confirmation of ATN by measuring urine sediment and urine electrolytes, notify nephrologist when serum creatinine level is $\geq 2.0 \mathrm{mg} / \mathrm{dL}$ ( $\geq 180$ $\mu \mathrm{mol} / \mathrm{L})$.

7. Note the projected need for dialysis: oliguric ATN (urine volume $<400$ $\mathrm{mL} / 24 \mathrm{hr}$ ), $85 \%$ of patients; nonoliguric ATN (urine volume $>400$ $\mathrm{mL} / 24 \mathrm{hr}$ ), $30 \%$ to $40 \%$ of patients.

8. Avoid excessive fluid "resuscitation" leading to pseudo acute respiratory distress syndrome, ventilator support, and multiorgan complications.

9. Avoid hypotension. Generally, there is no need to treat hypertension aggressively in the absence of a hypertensive crisis (acute end-organ damage).

10. Maintain fluid balance and treat hyperkalemia. Do not use "renal-dose" dopamine.

11. For patients with acute renal failure, review patient's active medications for necessary dose adjustments.

12. When indicated, use enteral rather than parenteral alimentation.

13. Discuss timing for initiation and mode of renal replacement with nephrologists (intermittent vs. continuous hemodialysis; daily dialysis in catabolic patients [e.g., those with sepsis or rhabdomyolysis]); discuss use of biocompatible membrane.

* ATN $=$ acute tubular necrosis

higher rates of liver failure. After adjustment for these factors, ICU or hospital mortality did not differ between groups. However, complete renal recovery was more likely in the continuous group, and hospital length of stay was shorter. The mode of dialysis has not been shown to affect mortality; however, continuous methods are becoming an important mode of therapy in the ICU because they allow treatment of hypotensive patients and manage control of fluids, electrolytes, and solute, particularly when large volumes of total parenteral nutrition are used (97).

\section{CONCLUSION}

Extensive new information about the diagnosis and management of acute renal failure has recently emerged. Table 3 summarizes recommendations for care of the patient with acute renal failure. These recommendations are based in part on evidence from recent studies and in part on clinical judgment. Well-designed multicenter clinical

5 November 2002 Annals of Internal Medicine $\mid$ Volume $137 \cdot$ Number $9 \mid 749$ 
trials to test methods for altering the course of ATN, decreasing the need for dialysis, and improving survival are badly needed to strengthen evidence-based conclusions.

From University of Colorado Health Sciences Center, Denver, Colorado.

Grant Support: By National Institutes of Health grants DK52599 and DK07135.

Requests for Single Reprints: Robert W. Schrier, MD, University of Colorado Health Sciences Center, Box B178, 4200 East 9th Avenue, Denver, CO 80262; e-mail, robert.schrier@uchsc.edu.

Current author addresses are available at www.annals.org.

\section{References}

1. Thadhani R, Pascual M, Bonventre JV. Acute renal failure. N Engl J Med. 1996;334:1448-60. [PMID: 8618585]

2. Liaño F, Pascual J. Epidemiology of acute renal failure: a prospective, multicenter, community-based study. Madrid Acute Renal Failure Study Group. Kidney Int. 1996;50:811-8. [PMID: 8872955]

3. Anderson R, Schrier RW. Acute renal failure. In: Schrier RW, ed. Diseases of the Kidney and Urinary Tract. 7th ed. Philadelphia: Lippincott Williams \& Wilkins; 2001.

4. Moran SM, Myers BD. Course of acute renal failure studied by a model of creatinine kinetics. Kidney Int. 1985;27:928-37. [PMID: 4021321]

5. Myers BD, Moran SM. Hemodynamically mediated acute renal failure. N Engl J Med. 1986;314:97-105. [PMID: 3510383]

6. Mehta RL. Acute renal failure in the intensive care unit: which outcomes should we measure? Am J Kidney Dis. 1996;28(Suppl 3):S74-80.

7. Feest TG, Round A, Hamad S. Incidence of severe acute renal failure in adults: results of a community based study. BMJ. 1993;306:481-3. [PMID: 8448456]

8. Schrier RW, Abraham E. Aggressive volume expansion and pseudo-ARDS [Editorial]. Hosp Pract (Off Ed). 1995;30:19, 23. [PMID: 7782392]

9. Miller TR, Anderson RJ, Linas SL, Henrich WL, Berns AS, Gabow PA, et al. Urinary diagnostic indices in acute renal failure: a prospective study. Ann Intern Med. 1978;89:47-50. [PMID: 666184]

10. Corwin HL, Schreiber MJ, Fang LS. Low fractional excretion of sodium. Occurrence with hemoglobinuric- and myoglobinuric-induced acute renal failure. Arch Intern Med. 1984;144:981-2. [PMID: 6712414]

11. Fang LS, Sirota RA, Ebert TH, Lichtenstein NS. Low fractional excretion of sodium with contrast media-induced acute renal failure. Arch Intern Med. 1980; 140:531-3. [PMID: 7362385]

12. Zarich S, Fang LS, Diamond JR. Fractional excretion of sodium. Exceptions to its diagnostic value. Arch Intern Med. 1985;145:108-12. [PMID: 3970621]

13. Vaz AJ. Low fractional excretion of urine sodium in acute renal failure due to sepsis. Arch Intern Med. 1983;143:738-9. [PMID: 6838295]

14. Liano F, Junco E, Pascual J, Madero R, Verde E. The spectrum of acute renal failure in the intensive care unit compared with that seen in other settings. The Madrid Acute Renal Failure Study Group. Kidney Int. 1998;53(Suppl 66): S16-24.

15. Bonomini V, Stefoni S, Vangelista A. Long-term patient and renal prognosis in acute renal failure. Nephron. 1984;36:169-72. [PMID: 6700808]

16. Kjellstrand CM, Ebben J, Davin T. Time of death, recovery of renal function, development of chronic renal failure and need for chronic hemodialysis in patients with acute tubular necrosis. Trans Am Soc Artif Intern Organs. 1981; 27:45-50. [PMID: 7331111]

17. Druml W, Lax F, Grimm G, Schneeweiss B, Lenz K, Laggner AN. Acute renal failure in the elderly 1975-1990. Clin Nephrol. 1994;41:342-9. [PMID: 8076437]

18. Chertow GM, Christiansen CL, Cleary PD, Munro C, Lazarus JM. Prog-

750|5 November 2002 Annals of Internal Medicine $\mid$ Volume 137• Number 9 nostic stratification in critically ill patients with acute renal failure requiring dialysis. Arch Intern Med. 1995; 155:1505-11. [PMID: 7605152]

19. Brivet FG, Kleinknecht DJ, Loirat P, Landais PJ. Acute renal failure in intensive care units - causes, outcome, and prognostic factors of hospital mortality; a prospective, multicenter study. French Study Group on Acute Renal Failure. Crit Care Med. 1996;24:192-8. [PMID: 8605788]

20. Neveu H, Kleinknecht D, Brivet F, Loirat P, Landais P. Prognostic factors in acute renal failure due to sepsis. Results of a prospective multicentre study. The French Study Group on Acute Renal Failure. Nephrol Dial Transplant. 1996; 11:293-9. [PMID: 8700363]

21. Liaño F, Gallego A, Pascual J, García-Martín F, Teruel JL, Marcén R, et al. Prognosis of acute tubular necrosis: an extended prospectively contrasted study. Nephron. 1993;63:21-31. [PMID: 8446248]

22. Paganini EP, Halstenberg WK, Goormastic M. Risk modeling in acute renal failure requiring dialysis: the introduction of a new model. Clin Nephrol. 1996;46:206-11. [PMID: 8879857]

23. Chertow GM, Lazarus JM, Paganini EP, Allgren RL, Lafayette RA, Sayegh $\mathrm{MH}$. Predictors of mortality and the provision of dialysis in patients with acute tubular necrosis. The Auriculin Anaritide Acute Renal Failure Study Group. J Am Soc Nephrol. 1998;9:692-8. [PMID: 9555672]

24. Paganini EP, Tapolyai M, Goormastic M, Halstenberg W, Kozlowski L, Leblanc M, et al. Establishing a dialysis therapy/patient outcome link in intensive care unit acute dialysis for patients with acute renal failure. Am J Kidney Dis. 1996;28(Suppl 3):S81-9.

25. Douma CE, Redekop WK, van der Meulen JH, van Olden RW, Haeck J, Struijk DG, et al. Predicting mortality in intensive care patients with acute renal failure treated with dialysis. J Am Soc Nephrol. 1997;8:111-7. [PMID: 9013455] 26. Levy EM, Viscoli CM, Horwitz RI. The effect of acute renal failure on mortality. A cohort analysis. JAMA. 1996;275:1489-94. [PMID: 8622223]

27. Molitoris BA, Weinberg JM, Venkatachalam MA, Zager RA, Nath KA, Goligorsky MS. Acute renal failure. II. Experimental models of acute renal failure: imperfect but indispensable. Am J Physiol. 2000;278:F1-12.

28. Star RA. Treatment of acute renal failure. Kidney Int. 1998;54:1817-31. [PMID: 9853246]

29. DuBose TD Jr, Warnock DG, Mehta RL, Bonventre JV, Hammerman MR, Molitoris BA, et al. Acute renal failure in the 21st century: recommendations for management and outcomes assessment. Am J Kidney Dis. 1997;29: 793-9. [PMID: 9159318]

30. Kelly KJ, Molitoris BA. Acute renal failure in the new millennium: time to consider combination therapy. Semin Nephrol. 2000;20:4-19. [PMID: 10651214]

31. Alkhunaizi AM, Schrier RW. Management of acute renal failure: new perspectives. Am J Kidney Dis. 1996;28:315-28. [PMID: 8804228]

32. Rudnick MR, Goldfarb S, Wexler L, Ludbrook PA, Murphy MJ, Halpern EF, et al. Nephrotoxicity of ionic and nonionic contrast media in 1196 patients: a randomized trial. The Iohexol Cooperative Study. Kidney Int. 1995;47:254-61. [PMID: 7731155]

33. Tepel M, van der Giet M, Schwarzfeld C, Laufer U, Liermann D, Zidek W. Prevention of radiographic-contrast-agent-induced reductions in renal function by acetylcysteine. N Engl J Med. 2000;343:180-4. [PMID: 10900277]

34. van Valenberg PL, Hoitsma AJ, Tiggeler RG, Berden JH, van Lier HJ, Koene RA. Mannitol as an indispensable constituent of an intraoperative hydration protocol for the prevention of acute renal failure after renal cadaveric transplantation. Transplantation. 1987;44:784-8. [PMID: 3122381]

35. Duggan KA, Macdonald GJ, Charlesworth JA, Pussell BA. Verapamil prevents posttransplant oliguric renal failure. Clin Nephrol. 1985;24:289-91. [PMID: 3907910]

36. Wagner K, Albrecht S, Neumayer HH. Prevention of posttransplant acute tubular necrosis by the calcium antagonist diltiazem: a prospective randomized study. Am J Nephrol. 1987;7:287-91. [PMID: 3318461]

37. Neumayer HH, Wagner K. Prevention of delayed graft function in cadaver kidney transplants by diltiazem: outcome of two prospective, randomized clinical trials. J Cardiovasc Pharmacol. 1987;10(Suppl 10):S170-7.

38. Dawidson I, Rooth P, Lu C, Sagalowsky A, Diller K, Palmer B, et al. Verapamil improves the outcome after cadaver renal transplantation. J Am Soc Nephrol. 1991;2:983-90. [PMID: 1760541]

39. Alcaraz A, Oppenheimer F, Talbot-Wright R, Fernández-Cruz L, Mañalich M, García-Pagés E, et al. Effect of diltiazem in the prevention of acute tubular 
Diagnosis and Treatment of Acute Tubular Necrosis 1 REVIEW

necrosis, acute rejection, and cyclosporine levels. Transplant Proc. 1991;23: 2383-4. [PMID: 1926395]

40. Tenschert W, Harfmann P, Meyer-Moldenhauer WH, Arndt R, Klosterhalfen $\mathrm{H}$. Kidney protective effect of diltiazem after renal transplantation with long cold ischemia time and triple-drug immunosuppression. Transplant Proc. 1991;23:1334-5. [PMID: 1989231]

41. Donnelly PK, Feehally J, Jurewicz A, Furness P, McCullough T, Harper SJ, et al. Renal transplantation: nifedipine for the nonstarters? A prospective randomised study. Transplant Proc. 1993;25:600-1. [PMID: 8438431]

42. Lustig S, Shmueli D, Boner G, Bar-Nathan N, Nakache R, Yussim A, et al. Gallopamil reduces the posttransplantation acute tubular necrosis in kidneys from aged donors. Isr J Med Sci. 1996;32:1249-51. [PMID: 9007165]

43. Chan C, Maurer J, Cardella C, Cattran D, Pei Y. A randomized controlled trial of verapamil on cyclosporine nephrotoxicity in heart and lung transplant recipients. Transplantation. 1997;63:1435-40. [PMID: 9175807]

44. Henderson IS, Beattie TJ, Kennedy AC. Dopamine hydrochloride in oliguric states. Lancet. 1980;2:827-8. [PMID: 6107501]

45. Flancbaum L, Choban PS, Dasta JF. Quantitative effects of low-dose dopamine on urine output in oliguric surgical intensive care unit patients. Crit Care Med. 1994;22:61-8. [PMID: 8124976]

46. Pavoni V, Verri M, Fenaro L, Volta CA, Paparella L, Capuzzo M, et al. Plasma dopamine concentration and effects of low dopamine doses on urinary output after major vascular surgery. Kidney Int. 1998;53(Suppl 66):S75-80.

47. Marik PE. Low-dose dopamine in critically ill oliguric patients: the influence of the renin-angiotensin system. Heart Lung. 1993;22:171-5. [PMID: 8449762] 48. Lindner A. Synergism of dopamine and furosemide in diuretic-resistant, oliguric acute renal failure. Nephron. 1983;33:121-6. [PMID: 6835459]

49. Parker S, Carlon GC, Isaacs M, Howland WS, Kahn RC. Dopamine administration in oliguria and oliguric renal failure. Crit Care Med. 1981;9: 630-2. [PMID: 7273808]

50. Epstein M, Schneider NS, Befeler B. Effect of intrarenal furosemide on renal function and intratenal hemodynamics in acute renal failure. Am J Med. 1975; 58:510-6. [PMID: 1124788]

51. Kleinknecht D, Ganeval D, Gonzalez-Duque LA, Fermanian J. Furosemide in acute oliguric renal failure. A controlled trial. Nephron. 1976;17:51-8. [PMID: 778649]

52. Brown CB, Ogg CS, Cameron JS. High dose frusemide in acute renal failure: a controlled trial. Clin Nephrol. 1981;15:90-6. [PMID: 7011622]

53. Shilliday IR, Quinn KJ, Allison ME. Loop diuretics in the management of acute renal failure: a prospective, double-blind, placebo-controlled, randomized study. Nephrol Dial Transplant. 1997;12:2592-6. [PMID: 9430857]

54. Chiao H, Kohda Y, McLeroy P, Craig L, Housini I, Star RA. Alphamelanocyte-stimulating hormone protects against renal injury after ischemia in mice and rats. J Clin Invest. 1997;99:1165-72. [PMID: 9077523]

55. Chiao H, Kohda Y, McLeroy P, Craig L, Linas S, Star RA. Alpha-melanocyte-stimulating hormone inhibits renal injury in the absence of neutrophils. Kidney Int. 1998;54:765-74. [PMID: 9734601]

56. Schafferhans K, Heidbreder E, Grimm D, Heidland A. Norepinephrineinduced acute renal failure: beneficial effects of atrial natriuretic factor. Nephron. 1986;44:240-4. [PMID: 2946967]

57. Nakamoto M, Shapiro JI, Shanley PF, Chan L, Schrier RW. In vitro and in vivo protective effect of atriopeptin III on ischemic acute renal failure. J Clin Invest. 1987;80:698-705. [PMID: 2957391]

58. Rahman SN, Kim GE, Mathew AS, Goldberg CA, Allgren R, Schrier RW, et al. Effects of atrial natriuretic peptide in clinical acute renal failure. Kidney Int. 1994;45:1731-8. [PMID: 7933821]

59. Allgren RL, Marbury TC, Rahman SN, Weisberg LS, Fenves AZ, Lafayette RA, et al. Anaritide in acute tubular necrosis. Auriculin Anaritide Acute Renal Failure Study Group. N Engl J Med. 1997;336:828-34. [PMID: 9062091]

60. Lewis J, Salem MM, Chertow GM, Weisberg LS, McGrew F, Marbury TC, et al. Atrial natriuretic factor in oliguric acute renal failure. Anaritide Acute Renal Failure Study Group. Am J Kidney Dis. 2000;36:767-74. [PMID: 11007679]

61. Hirschberg R, Kopple J, Lipsett P, Benjamin E, Minei J, Albertson T, et al. Multicenter clinical trial of recombinant human insulin-like growth factor I in patients with acute renal failure. Kidney Int. 1999;55:2423-32. [PMID: 10354291] 62. Acker CG, Singh AR, Flick RP, Bernardini J, Greenberg A, Johnson JP.
A trial of thyroxine in acute renal failure. Kidney Int. 2000;57:293-8. [PMID: 10620211]

63. Solez K, Morel-Maroger L, Sraer JD. The morphology of "acute tubular necrosis" in man: analysis of 57 renal biopsies and a comparison with the glycerol model. Medicine (Baltimore). 1979;58:362-76. [PMID: 481195]

64. Adams PL, Adams FF, Bell PD, Navar LG. Impaired renal blood flow autoregulation in ischemic acute renal failure. Kidney Int. 1980;18:68-76. [PMID: 7218661]

65. Conger JD, Robinette JB, Schrier RW. Smooth muscle calcium and endothelium-derived relaxing factor in the abnormal vascular responses of acute renal failure. J Clin Invest. 1988;82:532-7. [PMID: 3261301]

66. Kelleher SP, Robinette JB, Conger JD. Sympathetic nervous system in the loss of autoregulation in acute renal failure. Am J Physiol. 1984;246:F379-86. [PMID: 6720897]

67. Conger JD, Schultz MF, Miller F, Robinette JB. Responses to hemorrhagic arterial pressure reduction in different ischemic renal failure models. Kidney Int. 1994;46:318-23. [PMID: 7967342]

68. Wu AW, Rubin HR, Rosen MJ. Are elderly people less responsive to intensive care? J Am Geriatr Soc. 1990;38:621-7. [PMID: 2358623]

69. Zion MM, Balkin J, Rosenmann D, Goldbourt U, Reicher-Reiss H, Kaplinsky E, et al. Use of pulmonary artery catheters in patients with acute myocardial infarction. Analysis of experience in 5,841 patients in the SPRINT Registry. SPRINT Study Group. Chest. 1990;98:1331-5. [PMID: 2245670]

70. Polanczyk CA, Rohde LE, Goldman L, Cook EF, Thomas EJ, Marcantonio $\mathrm{ER}$, et al. Right heart catheterization and cardiac complications in patients undergoing noncardiac surgery: an observational study. JAMA. 2001;286:309-14. [PMID: 11466096]

71. Connors AF Jr, Speroff T, Dawson NV, Thomas C, Harrell FE Jr, Wagner $\mathrm{D}$, et al. The effectiveness of right heart catheterization in the initial care of critically ill patients. SUPPORT Investigators. JAMA. 1996;276:889-97. [PMID: 8782638]

72. Dalen JE, Bone RC. Is it time to pull the pulmonary artery catheter? [Editorial] JAMA. 1996;276:916-8. [PMID: 8782643]

73. Hayes MA, Timmins AC, Yau EH, Palazzo M, Hinds CJ, Watson D. Elevation of systemic oxygen delivery in the treatment of critically ill patients. N Engl J Med. 1994;330:1717-22. [PMID: 7993413]

74. Gattinoni L, Brazzi L, Pelosi P, Latini R, Tognoni G, Pesenti A, et al. A trial of goal-oriented hemodynamic therapy in critically ill patients. SvO2 Collaborative Group. N Engl J Med. 1995;333:1025-32. [PMID: 7675044]

75. Heyland DK, Cook DJ, King D, Kernerman P, Brun-Buisson C. Maximizing oxygen delivery in critically ill patients: a methodologic appraisal of the evidence. Crit Care Med. 1996;24:517-24. [PMID: 8625644]

76. Hébert PC, Wells G, Blajchman MA, Marshall J, Martin C, Pagliarello G, et al. A multicenter, randomized, controlled clinical trial of transfusion requirements in critical care. Transfusion Requirements in Critical Care Investigators, Canadian Critical Care Trials Group. N Engl J Med. 1999;340:409-17. [PMID: 9971864]

77. Rudis MI, Basha MA, Zarowitz BJ. Is it time to reposition vasopressors and inotropes in sepsis? Crit Care Med. 1996;24:525-37. [PMID: 8625645]

78. Abizaid AS, Clark CE, Mintz GS, Dosa S, Popma JJ, Pichard AD, et al. Effects of dopamine and aminophylline on contrast-induced acute renal failure after coronary angioplasty in patients with preexisting renal insufficiency. Am J Cardiol. 1999;83:260-3, A5. [PMID: 10073832]

79. Chertow GM, Sayegh MH, Allgren RL, Lazarus JM. Is the administration of dopamine associated with adverse or favorable outcomes in acute renal failure? Auriculin Anaritide Acute Renal Failure Study Group. Am J Med. 1996;101:4953. [PMID: 8686714]

80. Denton MD, Chertow GM, Brady HR. "Renal-dose" dopamine for the treatment of acute renal failure: scientific rationale, experimental studies and clinical trials. Kidney Int. 1996;50:4-14. [PMID: 8807566]

81. Lassnigg A, Donner E, Grubhofer G, Presterl E, Druml W, Hiesmayr M. Lack of renoprotective effects of dopamine and furosemide during cardiac surgery. J Am Soc Nephrol. 2000;11:97-104. [PMID: 10616845]

82. Bellomo R, Chapman M, Finfer S, Hickling K, Myburgh J. Low-dose dopamine in patients with early renal dysfunction: a placebo-controlled randomised trial. Australian and New Zealand Intensive Care Society (ANZICS) Clinical Trials Group. Lancet. 2000;356:2139-43. [PMID: 11191541]

5 November 2002 $\mid$ Annals of Internal Medicine $\mid$ Volume 137 • Number 9|751 
83. Leverve X, Bamoud D. Stress metabolism and nutritional support in acute renal failure. Kidney Int. 1998;53(Suppl 66):S62-6.

84. Cerra FB, Benitez MR, Blackburn GL, Irwin RS, Jeejeebhoy K, Katz DP, et al. Applied nutrition in ICU patients. A consensus statement of the American College of Chest Physicians. Chest. 1997;111:769-78. [PMID: 9118718]

85. Moore FA, Moore EE, Jones TN, McCroskey BL, Peterson VM. TEN versus TPN following major abdominal trauma-reduced septic morbidity. J Trauma. 1989;29:916-22; discussion 922-3. [PMID: 2501509]

86. Sandström R, Drott C, Hyltander A, Arfvidsson B, Scherstén T, Wickström I, et al. The effect of postoperative intravenous feeding (TPN) on outcome following major surgery evaluated in a randomized study. Ann Surg. 1993;217: 185-95. [PMID: 8439216]

87. Perioperative total parenteral nutrition in surgical patients. The Veterans Affairs Total Parenteral Nutrition Cooperative Study Group. N Engl J Med. 1991;325:525-32. [PMID: 1906987]

88. Heyland DK, MacDonald S, Keefe L, Drover JW. Total parenteral nutrition in the critically ill patient: a meta-analysis. JAMA. 1998;280:2013-9. [PMID: 9863853]

89. Battistella FD, Widergren JT, Anderson JT, Siepler JK, Weber JC, MacColl K. A prospective, randomized trial of intravenous fat emulsion administration in trauma victims requiring total parenteral nutrition. J Trauma. 1997;43: 52-8; discussion 58-60. [PMID: 9253908]

90. Conger JD. Interventions in clinical acute renal failure: what are the data? Am J Kidney Dis. 1995;26:565-76. [PMID: 7573008]

91. Abel RM, Beck CH Jr, Abbott WM, Ryan JA Jr, Barnett GO, Fischer JE. Improved survival from acute renal failure after treatment with intravenous essential L-amino acids and glucose. Results of a prospective, double-blind study. N Engl J Med. 1973;288:695-9. [PMID: 4631743]

92. Feinstein EI, Blumenkrantz MJ, Healy M, Koffler A, Silberman H, Massry SG, et al. Clinical and metabolic responses to parenteral nutrition in acute renal failure. A controlled double-blind study. Medicine (Baltimore). 1981;60:124-37. [PMID: 6783809]

93. Feinstein EI, Kopple JD, Silberman H, Massry SG. Total parenteral nutrition with high or low nitrogen intakes in patients with acute renal failure. Kidney Int. 1983;26(Suppl 16):S319-23.

94. Bellomo R, Seacombe J, Daskalakis M, Farmer M, Wright C, Parkin G, et al. A prospective comparative study of moderate versus high protein intake for critically ill patients with acute renal failure. Ren Fail. 1997;19:111-20. [PMID: 9044457]

95. Sponsel $\mathrm{H}$, Conger JD. Is parenteral nutrition therapy of value in acute renal failure patients? Am J Kidney Dis. 1995;25:96-102. [PMID: 7810542]

96. Kopple JD. The nutrition management of the patient with acute renal failure. JPEN J Parenter Enteral Nutr. 1996;20:3-12. [PMID: 8788257]

97. Conger J. Dialysis and related therapies. Semin Nephrol. 1998;18:533-40. [PMID: 9754606]

98. Hakim RM. Clinical implications of hemodialysis membrane biocompatibility [Editorial]. Kidney Int. 1993;44:484-94. [PMID: 8231020]

99. Schiffl H, Lang SM, König A, Strasser T, Haider MC, Held E. Biocompatible membranes in acute renal failure: prospective case-controlled study. Lancet. 1994;344:570-2. [PMID: 7914959]

100. Hakim RM, Wingard RL, Parker RA. Effect of the dialysis membrane in the treatment of patients with acute renal failure. N Engl J Med. 1994;331:133842. [PMID: 7935703]
101. Himmelfarb J, Tolkoff Rubin N, Chandran P, Parker RA, Wingard RL, Hakim R. A multicenter comparison of dialysis membranes in the treatment of acute renal failure requiring dialysis. J Am Soc Nephrol. 1998;9:257-66. [PMID: 9527402]

102. Kurtal H, von Herrath D, Schaefer K. Is the choice of membrane important for patients with acute renal failure requiring hemodialysis? Artif Organs. 1995;19:391-4. [PMID: 7625915]

103. Jones CH, Newstead CG, Goutcher E, Will EJ, Dean SG, Davison AM. Continuous dialysis for ARF in the ICU: choice of membrane does not influence survival [Abstract]. J Am Soc Nephrol. 1997;8:126A.

104. Jörres A, Gahl GM, Dobis C, Polenakovic MH, Cakalaroski K, Rutkowski B, et al. Haemodialysis-membrane biocompatibility and mortality of patients with dialysis-dependent acute renal failure: a prospective randomised multicentre trial. International Multicentre Study Group. Lancet. 1999;354: 1337-41. [PMID: 10533862]

105. Gastaldello K, Melot C, Kahn RJ, Vanherweghem JL, Vincent JL, Tielemans C. Comparison of cellulose diacetate and polysulfone membranes in the outcome of acute renal failure. A prospective randomized study. Nephrol Dial Transplant. 2000;15:224-30. [PMID: 10648669]

106. McCarthy JT. Prognosis of patients with acute renal failure in the intensivecare unit: a tale of two eras. Mayo Clin Proc. 1996;71:117-26. [PMID: 8577185] 107. Kleinknecht D, Jungers P, Chanard J, Barbanel C, Ganeval D. Uremic and nonuremic complications in acute renal failure: evaluation of early and frequent dialysis on prognosis. Kidney Int. 1972;1:190-6. [PMID: 4545907]

108. Conger JD. A controlled evaluation of prophylactic dialysis in posttraumatic acute renal failure. J Trauma. 1975;15:1056-63. [PMID: 1202238]

109. Gillum DM, Dixon BS, Yanover MJ, Kelleher SP, Shapiro MD, Benedetti RG, et al. The role of intensive dialysis in acute renal failure. Clin Nephrol. 1986;25:249-55. [PMID: 3720035]

110. Schiffl H, Lang S, Konig A, Held E. Dose of intermittent hemodialysis and outcome of acute renal failure: a prospective randomized study [Abstract]. J Am Soc Nephrol. 1997;8:290A.

111. Ronco C, Bellomo R, Homel P, Brendolan A, Dan M, Piccinni P, et al. Effects of different doses in continuous veno-venous haemofiltration on outcomes of acute renal failure: a prospective randomised trial. Lancet. 2000;356:26-30. [PMID: 10892761]

112. Schiffl H, Lang SM, Fischer R. Daily hemodialysis and the outcome of acute renal failure. N Engl J Med. 2002;346:305-10. [PMID: 11821506]

113. Bonventre JV. Daily hemodialysis—-will treatment each day improve the outcome in patients with acute renal failure? [Editorial] N Engl J Med. 2002; 346:362-4. [PMID: 1821514]

114. Lamiere N, Van Biesen W, Vanholder R, Colardijn F. The place of intermittent hemodialysis in the treatment of acute renal failure in the ICU patient. Kidney Int. 1998;53(Suppl 66):S110-9.

115. Forni LG, Hilton PJ. Continuous hemofiltration in the treatment of acute renal failure. N Engl J Med. 1997;336:1303-9. [PMID: 9113935]

116. Swartz RD, Messana JM, Orzol S, Port FK. Comparing continuous hemofiltration with hemodialysis in patients with severe acute renal failure. Am J Kidney Dis. 1999;34:424-32. [PMID: 10469851]

117. Mehta R, McDonald B, Gabbai F, Pahl M, Parkas A, Pascual M, et al. Continuous versus intermittent dialysis for acute renal failure (ARF) in the ICU: results from a randomized multicenter trial [Abstract]. J Am Soc Nephrol. 1996; 7:A1044. 
Current Author Addresses: Drs. Esson and Schrier: University of Colorado Health Sciences Center, Box B178, 4200 East 9th Avenue, Denver, CO 80262. 